JOURNAL OF SECURITY AND SUSTAINABILITY ISSUES

ISSN 2029-7017 print/ISSN 2029-7025 online

2020 June Volume 9 Number 4

http://doi.org/10.9770/jssi.2020.9.4(18).

Scopus

\title{
IMPACT OF DEMOGRAPHIC FACTORS ON RISK TOLERANCE
}

\author{
Firda Nosita $^{1 *}$, Kashan Pirzada², Tina Lestari³ ${ }^{3}$, Rosadiro Cahyono $^{4}$ \\ ${ }^{1,3,4}$ Sekolah Tinggi Ilmu Ekonomi Pancasetia, Jl. A. Yani KM. 5,5 Banjarmasin, 70248, Indonesia \\ ${ }^{2}$ College of BusinessTunku Puteri Intan Safinaz School of Accountancy, Universiti Utara Malaysia, Kedah, Malaysia \\ Email: 1*firda.nosita@gmail.com (Corresponding author)
}

Received 15 November 2019; accepted 10 April 2020; published 30 June 2020

\begin{abstract}
The Financial Services Authority of Indonesia (OJK) survey in 2016 has shown the financial literacy index in Indonesia was only about $21.8 \%$. A lot of illegal investment in Indonesian society in recent years proves that the Indonesian people have not fully understood the benefits and risks of financial decision making. The research describes demographic factor and risk tolerance in the context of Indonesia's society. The questionnaires distributed online and were obtained 850 respondents. To analyze the role of demographic factors on the willingness to take risks, we use Subjective Risk Tolerance, which is describing the respondent's perception of risk. The result indicates that gender and age statistically insignificant in describing risk tolerance. Meanwhile, marital status, income, and education significantly important in determining risk tolerance. Gender equality in the working environment means women and men have an equal chance to get job and position in a company. This chance also means that women have a great chance to get more income and wealth than before. Marital status related to responsibility, the greater the responsibility assumes the smaller the level of risk tolerance. The better the knowledge, the better the understanding of the financial decision. Information processed and used to make a better decision. The result shows that in order to conduct an education program and increasing society's knowledge, Government of the Republic of Indonesia, especially to The Indonesia Stock Exchange and Securities Firm should make attention to demographic factor and fit the investment product with investor's profile.
\end{abstract}

Keywords: risk tolerance; risk aversion; demographic factor; Indonesia; capital market

Reference to this paper should be made as follows: Nosita, F., Pirzada, K., Lestari, T., Cahyono, R. 2020. Impact of demographic factors on risk tolerance. Journal of Security and Sutainability Issues, 9(4): 1327-1336, http://doi.org/10.9770/jssi.2020.9.4(18).

JEL Classifications: G11, G32, G41

\section{Introduction}

A lot of illegal investment in Indonesia was correlated with the low of financial literacy of Indonesian. Financial literacy is a crucial factor in order to make a financial decision. Based on survey of The Financial Service Authority of Indonesia on 2016, the index of financial literacy in Indonesia was only about 29,66\%, and this means less literate. The Financial Service Authority of Indonesia (or Otoritas Jasa Keuangan/OJK) defined financial literacy as knowledge, interest, confidence and skill to manage their money. Financial literacy gives someone's ability to choose and utilize financial products and services.

Personal factors such as knowledge, willingness, risk preferences, and personal factors also play a role in investment decisions on financial assets. Pålsson (1996) conducted a study of more than 7,000 households in 1985 and found that risk aversion was very large but not systematic correlated with age variables. Women are generally considered more risk-averse than men (Watson and McNaughton, 2007). Watson and McNaughton (2007) found that women choose a conservative investment strategy compared to men and that lower income (which influences the number of members contributing to pension funds) is a major contributor to the benefits of lower pension funds for women. 
In general, every investment that generates small returns will create a risk that is also small, and vice versa. As a consequence, when an investor chooses to face a smaller risk, he will get a smaller return. So it is important to know the individual risk preferences before deciding where their capital will be invested.

Based on the problem stated above, the research question are (1) Does the demographic factor such as gender, age, marital status, income and education determine the risk tolerance? (2) Does the risk tolerance in man differ from women?

\section{Theoritical Background}

\section{Risk}

Risk is often associated with uncertainty. Knight (in Holton, 2004) concludes that only measurable uncertainty defined as risk. Holton (2004) argues that the two components needed for a risk. Firstly, the uncertainty about the possible results and secondly is the result must be considered in terms of providing utilities.

In term of financial discipline, risk is defined as the variability of actual returns on investment between expected returns. Risks are defined as deviations from the results that are received as expected (Hartono, 2015). While, Van Horne and Wachowics, Jr. (Hartono, 2015) defines risk as variability of actual returns to expected returns (Suryani, A. and Pirzada, 2018).

\section{Risk Avoidance in Women}

Byrnes, et al. (1999) explain differences in risk-taking between women and men, they show that women, on average, take less risk than men. For example, women are more likely to use seat belts when driving more than men and tend not to smoke (Hersch 1996). By using biological explanations, Zuckerman (Watson and McNaughton, 2007) explains that women and men differ in their chosen risk preferences. He explained that women produce more monoamine oxidase enzymes than men. This enzyme prevents the desire to search, thus limiting the level at which risk-taking occurs. Women adapt to risk intolerance because of their greater responsibility for reproduction and nurturing children, on the contrary, men are more willing to risk because of the ability (according to sociobiological theory) derived from success in risk competition (Wilson and Daly in Watson and McNaughton, 2007). Hersch (1996) concludes that longer women's chances of life mean that women will benefit more from risk avoidance because they will face the consequences of negative outcomes for a longer time.

Sociocultural reasons for men who are more likely be risk-tolerant than women (Felton, et al., 2002). Slovic (Watson and McNaughton, 2007) underlines that children are suppressed during their childhood (through peers and social expectations) to behave according to their gender culture role, which will result in a higher tendency for men to take risks. Byrnes, et al. (1999) concludes that more restrictive parental monitoring in girls during childhood may explain the increased ability to risk rejection behavior later on. Interestingly, several studies have shown that social change - for example, feminist movements in the 1960s and 1970s resulted in stereotypical changes in women and women's attitudes to risk. Research also shows that this change triggers a substantial increase in career women and women entrepreneurs (Master and Meier in Watson and McNaughton, 2007; Thandabhani, 2020).

Hinz et al.; Bajtelsmit and Vanderhei (in Watson and McNaughton, 2007) describe the choice of pension funds from investors in the United States and conclude that, with income and age control variables, women generally choose lower risk pension funds. Sundén and Surette (Watson and McNaughton, 2007) conclude that after marital status was added to their control variables, women still chose pension funds with lower risks. While Charness and Gneezy (2011) used several studies to prove the difference in the acceptance of risk between women and men. They conclude that there is very strong evidence that women invest less than men, therefore, financially more risk-averse than men.

Although the difference in wealth by sex is smaller, on average women still have lower levels of wealth than 
men (Bajtelsmit and Bernasek, 1996). A smaller level of income for women means that the resources available to save and invest are less than men. However, Hayhoe and Wilhelm's research (Bajtelsmit and Bernasek, 1996) found that there were no significant differences between women and men in terms of income control.

\section{Other Factors Role in Risk Avoidance}

Financial risk tolerance is defined as the maximum amount of uncertainty that a person can receive when making financial decisions, which is almost taken in every part of economic and social life (Grable, 2000). Jaggia and Thosar (2000) sought an inverse relationship between age and risk taking. They found that individuals with longer investment time horizons tend to allocate more parts of their portfolios to risk assets, not because of time considerations, but because they tolerate risk more. Most investment practitioners suggest the principle of time diversification, which states that portfolio risk is reduced when extending the investment horizon (Jaggia and Thosar, 2000). However, some theorists argue that time diversification is a false theory. Some psychological studies prove the opposite relationship between age and risk recipients (Jaggia and Thosar, 2000). Individual wealth or income is the second factor that controls risk avoidance. High wealth and income encourage risk tolerance because the wealth of investors can receive better losses than individuals who have less wealth. Hinz et al. (1997) found that lower incomes tend to face higher risk avoidance. Benzion and Yagil (2003) find that the proportion of wealth invested in risk assets increases with increasing wealth. Someone who has greater wealth will be more tolerant of risk (Susanto, Pirzada, and Adrianne, 2019). Knowledge, gained through both experience and education, is the third factor that contributes to controlling risk aversion. Riley and Chow (1992) found that investors with relatively low education invest more conservatively, even when income is used as a control variable. Christelis et al. (2008) that the tendency of investment in the capital market was closely related to cognitive abilities, both capital market participation and indirect participation such as mutual funds and pension funds. Cognitive abilities include mathematical abilities, verbal skills and memory skills (Wati, Primiana, Pirzada and Sudarsono, 2019). Other factors that might affect risk avoidance are marital status. Daly and Wilson (2001) suggest that increased responsibilities along with marriage and children will make men more risk tolerant. Sundén and Surette (Watson and McNaughton, 2007) found that marriage would make women and men more risk averse to their retirement choices. Säve-Söderbergh (Watson and McNaughton, 2007) argues that marriage will encourage couples to invest in more risky assets because each person currently has a second income that can guarantee the losses they incur. They also proposed that marriage also affects the risk preferences of women and men differently. Hawley and Fujii (1993) used the logit model to prove the effect of individual characteristics on risk tolerance. The study included respondents aged 25-62 years. The factors of education, income and debt have a positive effect on risk tolerance. Married couples and households headed by a man are more tolerant of risk than households headed by a woman. While the age variable does not have a significant effect. Christiansen, et al. (2013) found that women increased part of the wealth invested in shares after marriage and dropped them after divorce, while men showed the opposite behavior. Hartog, et al. (2000) found that women avoid risk more than men. By comparing respondents' job, they found that entrepreneurs were more willing to take risks than employees, while civil servants were more risk-averse than private sector employees. They also found that education and welfare negatively affected risk aversion. That is, the welleducated person tend to be risk tolerant. Whereas individual welfare associated with income, contributes negatively to risk avoidance, when a person achieves financial prosperity, they are more risk tolerant than the others. Hartog, et al. (2000) also found a positive relationship between age and risk avoidance, the elderly one are more likely risk-averse than younger. Faff, et al. (2008) also found that women tend to be more risk-averse than men. Whereas age has a nonlinear relationship with risk avoidance. In addition, wealth and income tend to have a relationship that is opposed to risk avoidance, which means that the greater a person's wealth and income, the less risk aversion. Chiappori and Paiella (2011) also found that wealth has a negative effect on one's risk avoidance. While, Wang and Hanna (1997) found that risk tolerance increases with age when other variables are controlled. That is, when age increases, risk tolerance decreases. By using students at Peking University as a sample, Ding, et al. (2010) asserted that women avoid risk more than men and avoidance of risk decreases as parents increase income. Dohmen, et al. (2011) used a survey to German people and found that the gender, age, height and background of parents significantly affected a person's willingness to take risks. It is proven that women in Germany are more risk-averse than men and greater risk aversion increases with age. Meanwhile, 
family background in terms of parental education appears to play a role in determining attitudes towards risk, which shows a positive relationship between parental education and the willingness to take risks. Finally, he also found that someone who has a higher body is more risk tolerant.

\section{Research Methodology}

The questionnaires distributed online through Google forms. Data were obtained from 850 samples which gained from cluster sampling. By using data from the Central Bureau of Statictics of Indonesia (Badan Pusat Statistik Indonesia) on 2010, the percentage of the population in each zona is $79.8 \%$ for the West, $17.5 \%$ for the Central region and $2.7 \%$ for the East, table 1 represent the amount sample for each zona. For the purpose of this study, it was hypothesized that (a) women more risk-averse than men (b) risk avoidance would increase as age increases (c) marital status affects a person's risk tolerance, (d) risk avoidance will decrease along with increased income, (e) the level of education will be related to risk avoidance (see table 1 and table 2).

Table 1. Number of Sample

\begin{tabular}{|c|c|c|}
\hline Zone & Percentage & Sample Amount \\
\hline West & $79.8 \%$ & 150 \\
\hline Central & $17.5 \%$ & 22 \\
\hline East & $2.7 \%$ & 850 \\
\hline Total & $100 \%$ & 150 \\
\hline
\end{tabular}

Source: data processing

Respondents were asked to fill out questionnaires containing statements about their willingness to take risks with various decision alternatives made using a Likert scale. Starting from Scale one, shows the reluctance to take risks up to five that describes a very high-risk tolerance. Statement regarding risk tolerance is divided into six statements that reflect a person's perception of a condition related to decision making. This perception factor will capture several dimensions of investment such as perceptions about security, protection and perceptions about the definition of risk. The regression model as follows:

$$
S R T=\beta_{0}+\beta_{1} \text { Gender }+\beta_{2} \text { Age }+\beta_{3} M S+\beta_{4} \text { Inc }+\beta_{5} E d u+e
$$

Where:

\section{SRT}

Gender

Age

MS / Marital Status

Inc / Income

Edu / Education
$=$ Subjective Risk Tolerance,

$=$ dummy variable for gender, 1 for male and 0 for woman

$=$ age group of respondents, codes 1 to 5 according to the age group

$=$ respondent's marital status

$=$ income group of respondents, codes 1 to 5 according to the income group of respondents per month

$=$ Respondent's Education Level, codes 1 to 4 according to the respondent's last Education.

Table 2. Subjective Risk Tolerance Indicator

\begin{tabular}{|c|c|l|}
\hline No & Perception & \multicolumn{1}{c|}{ Indicators } \\
\hline 1 & Safety & $\begin{array}{l}\text { - Satisfied with the result, do not take an opportunity to get the potential higher return although have a } \\
\text { greater chance } \\
\text { - Do not do anything out of the ordinary to reduce risk }\end{array}$ \\
\hline 2 & Hedging & $\begin{array}{l}\text { - Transfer of risk to reduce losses } \\
\text { - More concerned about possible losses than possible profits }\end{array}$ \\
\hline 3 & Risk Definition & - Risk is loss \\
\hline
\end{tabular}




\section{Result}

Characteristics of respondents based on gender, age, marital status, income level, and education can be seen in the following table 3 :

Table 3. Respondent's Profile

\begin{tabular}{|c|c|c|c|c|c|}
\hline & & \multicolumn{2}{|c|}{ Man } & \multicolumn{2}{|c|}{ Women } \\
\hline & & Amount & Percentage & Amount & Percentage \\
\hline \multirow[t]{5}{*}{ Age } & $\leq 25$ & 186 & $21,89 \%$ & 229 & $26,95 \%$ \\
\hline & $25-34$ & 150 & $17,65 \%$ & 124 & $14,60 \%$ \\
\hline & $35-44$ & 65 & $7,65 \%$ & 36 & $4,24 \%$ \\
\hline & $44-54$ & 32 & $3,76 \%$ & 17 & $2 \%$ \\
\hline & $\geq 55$ & 9 & $1,06 \%$ & 2 & $0,2 \%$ \\
\hline \multirow[t]{3}{*}{ Marital Status } & Single & 245 & $28,82 \%$ & 270 & $31,77 \%$ \\
\hline & Married, no children & 41 & $4,83 \%$ & 38 & $4,47 \%$ \\
\hline & Married with children & 156 & $18,35 \%$ & 100 & $11,76 \%$ \\
\hline Monthly & $\leq$ Rp. 2.000 .000 & 84 & $9,89 \%$ & 108 & $12,71 \%$ \\
\hline Income & Rp. $2.000 .001-$ Rp. 3.0000 .000 & 64 & $7,52 \%$ & 57 & $6,70 \%$ \\
\hline \multirow[t]{3}{*}{ (Indonesia Rupiahs) } & Rp. 3.000.0001 - Rp. 4.000 .000 & 47 & $5,53 \%$ & 58 & $6,82 \%$ \\
\hline & Rp. 4.000.001 - Rp. 5.000 .000 & 90 & $10,59 \%$ & 79 & $9,30 \%$ \\
\hline & $\geq$ Rp. 5.000 .001 & 157 & $18,47 \%$ & 106 & $12,47 \%$ \\
\hline \multirow[t]{4}{*}{ Education } & High School & 72 & $8,47 \%$ & 42 & $4,93 \%$ \\
\hline & Diploma & 33 & $3,89 \%$ & 25 & $2,94 \%$ \\
\hline & Bachelor's degree & 269 & $31,65 \%$ & 278 & $32,71 \%$ \\
\hline & Postgraduate & 68 & $8 \%$ & 63 & $7,41 \%$ \\
\hline
\end{tabular}

Source: data processing

The most respondents were single and passed bachelor's degree. Regression results can be seen as follows (table 4):

Table 4. Regression Result

$$
\left(S R T=\beta_{0}+\beta_{1} \text { Gender }+\beta_{2} \text { Age }+\beta_{3} M S+\beta_{4} \text { Inc }+\beta_{5} E d u+e\right)
$$

\begin{tabular}{|c|c|c|c|}
\hline & Coef & $\mathrm{t}$ & sig \\
\hline C & 12.075 & 7.349 & 0.000 \\
Gender & -0.407 & -1.279 & 0.201 \\
Age & 0.341 & 1.364 & 0.173 \\
Marital Status & -0.691 & -2.735 & 0.006 \\
Income & 0.775 & 6.778 & 0.000 \\
Education & 0.510 & 2.493 & 0.013 \\
\hline $\mathrm{R}^{2}$ & 0.111 & Adj R & 0.105 \\
\hline
\end{tabular}

Source: Computed output (2019) 


\section{Discussion}

Table 4 shows that men and women have no differences in risk tolerance. This means that gender does not influence the risk avoidance of a person, both men and women and does not necessarily determine how risk tolerance they are. Feminist movements in the 1960s and 1970s resulted in women's stereotypical changes and women's attitudes to risk. Research also shows that this change triggers a substantial increase in women entrepreneurs and career women (Master and Meier in Watson and McNaughton, 2007). Based on the results of Grant Thornton's survey (cnnindonesia.com, 2016) concluded that Indonesia was ranked sixth as the country with the highest percentage that gave a high position in the company to women with a $36 \%$ share. Global trends show that developing countries are increasingly opening up opportunities for women to become leaders or occupy important positions in a company or organization. As a result, women also get income equal to their responsibilities and allow them to compete with men in generating wealth. The Central Bureau of Statictics of Indonesia (Badan Pusat Statistik / BPS, 2018) also noted that the percentage of formal workers for women continued to increase from 2015 to 2017, especially in the productive age. This is of course in line with the increasing capability of women with formal and non-formal education. It can be seen from table 3, the percentage of female respondents in this study had almost equally educated as men (especially in undergraduate and postgraduate degree), which proves that women's capabilities are not inferior to men thus run the chance to get a career or a good job and give a high salary. High salaries or income can affect a person in making financial decisions. In accordance with the results of this study, the higher income, the more risk-tolerant they are. Table 4 shows that the age does not affect a person's risk avoidance. The results of this study contradict to Lee and Hanna (in Adhikari and O'Leary, 2008) who found that a person's risk tolerance decreases with age. In this study, they have the same view of risk. Hawley and Fujii (1993) also prove that age variables do not significantly influence risk aversion. Risk avoidance is not only influenced by a person's age but can be related to the investment time horizon. If someone has a longer time to invest, he might be more tolerant of risk than someone who has a shorter time. The results of the study are also in line with Cornelis and Linawati (2015) who found that age does not have a significant influence on risk tolerance. The same investment opportunity and ease of access to information make everyone easily find information to be processed in the context of decision making. Information is crucial in the decision-making process in relation to risk avoidance. Increasingly fast, accurate and diverse information is a person's capital to manage that information into a decision. Diversification is a way to manage or minimize risks. In addition, someone will diversify with the aim of maximizing returns. A young person will tend to diversify by looking for more diverse instruments with the aim of maximizing returns. Whereas an older person will also diversify to maintain the prosperity he has today. In addition, both young and old person will look for alternative investments that are appropriate to their character and goals. In this study, marital status has a significant negative effect on risk tolerance. This means that someone who is married and has children will be more risk-averse than someone who is married but does not have children, and someone who is not married is more risk-tolerant. This is in line with the results of research by Daly and Wilson (2001) concluding that responsibility increases along with marriage and having children, a man becomes more risk averse. In line with these findings, Sunden and Surette (in Adhikari and O'Leary, 2008) found that marriage makes a person, both men and women more risk-averse to their retirement plan choices. Jianakoplos and Bernasek (1998) found that the presence of children significantly increased the risk tolerance of married couples but decreased risk tolerance for single women (Arniati, Puspita, Amin and Pirzada 2019). This is reasonable, someone who is married has responsibility for his partner and will be more selective in making decisions, especially financial decisions. When married couples have children, they will be more concerned about risk and try to reduce risk by transferring risks, namely buying health insurance, education insurance and life insurance. The risk transfer is effort to reduce uncertainty in the future, where uncertainty is closely related to risk. Someone who is single may be more willing to take risks because of limited responsibility for themselves, especially if they have personal income that can be freely used to make investment decisions. A married person, especially who has a child will be very aware of the increase in living costs reflected in the inflation rate. Inflation will describe the costs of living such as health costs and education costs. Many married couples avoid the health, education and soul risks by transferring risk to insurance institutions. This shows that married couples and/or having children are more risk-averse and try to manage it by purchasing insurance. The survey results of the Financial Services Authority of Indonesia on 2013 and 2016 show that public literacy towards insurance institutions is far greater than 
the public literacy of the capital market. In 2013, the survey results showed that insurance literacy was $17.84 \%$ compared to capital market literacy which was only 3.79\%. Despite experiencing an increase in 2016, capital market literacy is still relatively low, which is only $4.40 \%$. The results of this survey emphasize that people are more aware and understand insurance products and may be related to their attitude to risk. Based on table 4, the income variable has a significant positive relationship to risk tolerance. This means that the greater a person's income, the higher their tolerance for risk. Faff, et al. (2008) also found that wealth and income tend to have a relationship that is opposed to risk avoidance, which means that the greater a person's wealth and income, the less risk aversion. Chiappori and Paiella (2011) found that a person's relative risk avoidance is fixed and wealth has a negative effect on one's risk avoidance. It is a common situation, someone with high income becomes more tolerant of risk because they assume risk is an opportunity to get returns on their financial decisions. A person with lower income will be more risk-averse because they assume that financial decisions do provide opportunities for returns, but must be considered carefully so as not to reduce their welfare, so they are more careful in making financial decisions. The results show that education influences a person's risk avoidance. This emphasizes that the level of education of a person influences their attitude towards risk. The higher the level of education of a person, the more tolerant of risk. This is quite reasonable because education is a person's capital in conducting analysis in relation to decision making. The higher a person's education, the greater their knowledge and capability in processing information and making financial decisions. Lee and Hanna (in Adhikari and O'Leary, 2008) also found that risk tolerance increases with the level of one's education. Someone with a higher education becomes more risk-tolerant and takes risks. This can be caused by the knowledge and level of analysis of someone who is more mature as his education. Riley and Chow (1992) found that investors with relatively low education invest more conservatively, even when income is used as a control variable. While investors who have relatively high education tend to be more aggressive or tolerant of risk.

\section{Conclusions}

We conclude that gender and age are not relevant to risk-aversion. Both man and women did not have any difference in risk tolerance. Old and young people is proven not to influence a person's tendency to avoid or take risks. Meanwhile, marital status determines a person's risk avoidance profile. The higher a person's income, the greater the risk tolerance. Income is a person's capital in making investment decisions. The assumption is that people who had good welfare tend to be more tolerant of risks, such as potential losses in investment. Conversely, low income will trigger someone to be more careful in making investment decisions. Education is a factor that must be considered in disseminating information about investment products. Education is an important element in shaping a person's logic or analysis in making financial or investment decisions. Education provides knowledge and if combined with skills will make a person become more confident in making investment decisions. Based on the results, The Indonesia Stock Exchange together with The Financial Services Authority of Indonesia (OJK) should pay attention to demographic factors when going to socialize the capital market. The Indonesian Stock Exchange and Securities Company may use a person's risk profile to provide an understanding to the public about the appropriate product features, for example on the benefits and risks, rights and obligations, how to access and transaction mechanisms for financial products or investments in the capital market. The IDX and Securities Companies must adjust investment products offered with the characteristics of target investors. Target investors who have a low income, for example, can be given knowledge about investment products that tend to be safe such as mutual funds or bonds. This study did not, as yet, compare the risk tolerance of Indonesian society with neighboring countries such as Singapore or Malaysia in order to explain how risk tolerance affects a person's confidence in investing in the capital market which differentiates their capital market literacy.

\section{References}

Adhikari, B, K., \& Leary, V. E. (2008). Gender Differences in Risk Aversion: A Study of Nepalese Banking Sector Employees. Kathmandu University School of Management Occasional Paper, 2, 1-20

Arniati, T.; Puspita, D.A.; Amin, A.; Pirzada, K. 2019. The implementation of good corporate governance model and auditor independence in earnings' quality improvement, Entrepreneurship and Sustainability Issues 7(1): 188-200. http://doi.org/10.9770/jesi.2019.7.1(15)

Atkinson, A. \& Messy F-A. (2012). Measuring Financial Literacy: Results of the OECD/International Network on Financial Education 
(INFE) Pilot Study. OECD Working Papers on Finance, Insurance and Private Pensions. 15

Bajtelsmit, V. L \& Bernasek, A. (1996). Why Do Women Invest Differently Than Men?. Financial Counseling and Planning, 7, 1-10. http://dx.doi.org/10.2139/ssrn.2238

Benzion, U \& Yagil, J. (2003). Portfolio Composition Choice: A Behavioral Approach. The Journal of Behavioral Finance, 4(2): 85-95. http://dx.doi.org/10.1207/S15427579JPFM0402_05

Brown, D. A. (2007). Pension and Risk Aversion: The Influence of Race, Ethnicity, and Class on Investor Behavior. Lewis and Clark Law Review, 11(2): 385-406.

Byrnes, J. P., Miller, D. C \& Schafer, W.D. (1999). Gender Differences in Risk Taking: A Meta-Analysis. Psychological Bulletin, 125(3): 367-383. http://dx.doi.org/10.1037/0033-2909.125.3.367

Campbell, J. Y \&. Viceira, L. M. (2002). Strategic Asset Allocation: Portfolio Choice for Long-Term Investors. OUP Oxford.

Carducci, B. J \& Wong, A. S. (1998). Type A and Risk Taking in Everyday Money Matters. Journal of Business and Psychology, 12(3): 355-359.

Caesario, E, B. BEI Catatkan Jumlah Investor Saham Capai 710.000 SID. Retrieved June 29, 2018, from http://market.bisnis.com/ $\mathrm{read} / 10180625 / 190 / 809145 /$ bei-catatkan-jumlah-investor-saham-capai-710.000-sid.

Carpena, F., Cole, S., Shapiro, J \& Zia, B. (2011). Unpacking the Causal Chain of Financial Literacy. Policy Research Working Paper. 5798. The World Bank Development Research Group Finance and Private Sector Development Team. http://dx.doi.org/10.1596/18139450-5798

Charness, G \& Gneezy, U. (2012). Strong Evidence for Gender Differences in Risk Taking. Journal of Economic Behavior \& Organization, 83(1): 50-58. http://dx.doi.org/10.1016/j.jebo.2011.06.007

Chiappori, P-A \& Paiella, M. (2011). Relative Risk Aversion is Constant: Evidence from Panel Data. Journal of the European Economic Association, 9(6): 1021-1052. http://dx.doi.org/10.1111/j.1542-4774.2011.01046.x

Christelis, D., Jappelli, T \& Padula, M. (2010). Cognitive Abilities and Portfolio Choice. European Economic Review, 54(1): 18-38. http:// dx.doi.org/10.1016/j.euroecorev.2009.04.001

Christiansen, C., Joensen, J. S \& Rangvid, J. (2013). Understanding the Effects of Marriage and Divorce on Financial Investments: The Role of Background Risk Sharing. Economic Inquiry, 53(1): 431-447. http://dx.doi.org/10.1111/ecin.12113

Cornelis, Y \& Linawati, N. (2015). Toleransi Risiko pada Pasangan yang Sudah Menikah. Finesta, 3 (2): 39-43.

Daly, M \& Wilson, M. (2001). Risk-Taking, Intrasexual Competition, and Homicide. Nebraska Symposium on Motivation, 47: 1-36.

Ding, X., Hartog, J. \& Sun, Y. (2010). Can We Measure Individual Risk Attitudes In A Survey?. Tinbergen Institute Discussion Paper, Amsterdam, 027(3).

Dohmen, T., Falk, A., Huffman, D., Suende, U., Schupp, J \& Wagner, G. G., et al. (2011). Individual Risk Attitudes: Measurement, Determinants, And Behavioral Consequences. Journal of the European Economic Association, 9(3): 522-550. http://dx.doi.org/10.1111/ j.1542-4774.2011.01015.x

Dow, J \&. Werlang, S. R. D. (1992). Uncertainty Aversion, Risk Aversion, And the Optimal Choice of Portfolio. Econometrica: Journal of the Econometric Society, 60(1) 197-204. http://dx.doi.org/10.2307/2951685

Faff, R., Mulino, D \& Chai, D. (2008). On The Linkage Between Financial Risk Tolerance And Risk Aversion. Journal of Financial Research, 31(1): 1-23. http://dx.doi.org/10.1111/j.1475-6803.2008.00229.x

Felton, J., Gibson, B \& Sanbonmatsu, D. M. (2003). Preference For Risk In Investing As A Function of Trait Optimism And Gender. The Journal of Behavioral Finance, 4(1): 33-40. http://dx.doi.org/10.1207/S15427579JPFM0401_05

Financial Service Authourity (OJK). 2017. National Strategy of Indonesian Financial Literacy. (Revisit 2017).

Grable, J. E. (2000). Financial Risk Tolerance and Additional Factors That Affect Risk Taking in Everyday Money Matters. Journal of Business and Psychology, 14(4): 625-630.

Graham, B. (2003). The Intelligent Investor: Ajaran-ajaran Inti dalam Berinvestasi. Edisi Revisi, Pijar Nalar Indonesia. Depok. (Original work published 1973). 
Hanafi, M. M. (2016). Manajemen Risiko. Edisi Ketiga, UPP STIM YKPN. Yogyakarta.

Hartog, J., Jonker, N \& Ferrer-i-Carbonell, A. (2000). On A Simple Measure of Individual Risk Aversion. Tinbergen Institute Discussion Paper, Amsterdam, 00-074/3.

Hartono, J. (2015). Teori Portofolio dan Analisis Investasi. Edisi Kesepuluh. BPFE Yogyakarta.

Hawley, C. B \& Fujii, E. T. (1993). An Empirical Analysis of Preferences for Financial Risk: Further Evidence On The Friedman-Savage Model. Journal of Post Keynesian Economics, 16(2): 197-204. http://dx.doi.org/10.1080/01603477.1993.11489978

Hersch, J. (1996). Smoking, Seat Belts, and Other Risky Consumer Decisions: Differences by Gender and Race. Managerial and Decision Economics, 17(5): 471-481. http://dx.doi.org/10.1002/(SICI)1099-1468(199609)17:5\%3C471::AID-MDE789\%3E3.0.CO;2-W

Hinz, R. P., McCarthy, D. D. \& Turner, J. A. (1997). Are Women Conservative Investors? Gender Differences in Participant-Directed Pension Investments. In Positioning Pensions for the Twenty-First Century. Edited by Gordon M.S., Mitchell, O. S \& Twinney, M. M. University of Pennsylvania Press. Philadelphia.

Holton, G. A. (2004). Defining Risk. Financial Analyst Journal, 60(6): 19-25

Hung, A., Yoong, J \& Brown, E. (2012). Empowering Women Through Financial Awareness and Education. OECD Working Papers on Finance, Insurance and Private Pensions, No. 14.

Indonesia Central Bureau of Statistik (BPS). The Percentage of Formal Labor by Gender, 2015-2017. Retrieved September $20,2018$. http://www.bps.go.id.

Jacob, K., Hudson, S \& Bush, M. (2000). Tools for Survival: An Analysis of Financial Literacy Programs for Lower-Income Families. Woodstock Institute.

Jaggia, S \& Thosar, S. (2000). Risk Aversion and The Investment Horizon: A New Perspective on The Time Diversification Debate. The Journal of Psychology and Financial Markets, 1(3-4): 211-215. http://dx.doi.org/10.1207/S15327760JPFM0134_6

KPEI newsletter. Edisi 1 Triwulan I 2017. PT. Kliring Penjaminan Efek Indonesia.

Kurihara, Y. (2013). Does Financial Skill Promote Economic Growth? International Journal of Humanities and Social Science, 3(8): 92-97.

Lusardi, A. \& Mitchell, O. S. (2007). Financial Literacy and Retirement Preparedness: Evidence and Implications for Financial Education, Business Economics.

Otoritas Jasa Keuangan. Survei Nasional Literasi dan Inklusi Keuangan 2016. Retrieved May 5, 2017 from https://sikapiuangmu.ojk. go.id.

Pålsson, A. M. (1996). Does the Degree of Risk Aversion Vary With Household Characteristics? Journal of Economic Psychology, 17(6): 771-787. http://dx.doi.org/10.1016/S0167-4870(96)00039-6

Priherdityo, E. Wanita Karir Indonesia Terbanyak Keenam di Dunia. Retrieved September 20, 2018 from http://www.m.cnnindonesia. com.

Remund, D. L. (2010). Financial Literacy Explicated: The Case for a Clearer Definition in an Increasingly Complex Economy, The Journal if Consumer Affairs, 44(2): 276-295. http://dx.doi.org/10.1111/j.1745-6606.2010.01169.x

Riley Jr., W. B \& Chow, K. V. (1992). Asset Allocation and Individual Risk Aversion. Financial Analysts Journal, 48(6): 32-37. http:// dx.doi.org/10.2469/faj.v48.n6.32

Santoso, W. (2018). Retrieved September 18, 2018 from https://ekonomi.kompas.com/read/2018/05/25/150600526/ojk--kerugian-akibatinvestasi-ilegal-lebih-dari-rp-100-triliun

Säve-Söderbergh, J. (2003). Essay on Gender Differences in Economic Decision-Making. PhD thesis, Stockholm University.

Sung, J \& Hanna, S. D. (1996). Factors Related to Risk Tolerance. Journal of Financial Counseling and Planning, 7: 11. http://dx.doi. org/10.2139/ssrn.2234

Suryani, A., \& Pirzada, K. (2018). Analysis of opportunistic behavior of management to company performance. Polish Journal of Management Studies, 18(1): 379-388. http://doi.org/10.17512/pjms.2018.18.1.28 
Susanto, Y. K., Pirzada, K., \& Adrianne, S. (2019). Is tax aggressiveness an indicator of earnings management?. Polish Journal of Management Studies, 20(2): 516-527. http://doi.org/10.17512/pjms.2019.20.2.43

Thandabhani, M. 2020. Strategic communication for women entrrepreneurs: a case study of India. Insights into Regional Development, 2(1): 480-497. http://doi.org/10.9770/IRD.2020.2.1(7)

Tustin, D. H. (2010). An Impact Assessment of a Prototype Financial Literacy Flagship Programme in a Rural South African Setting. African Journal of Business Management, 4(9): 1894-1902.

Wang, H \& Hanna, S. (1997). Does Risk Tolerance Decrease with Age? Financial Counseling and Planning, 8(2): 27-31. http://dx.doi. org/10.2139/ssrn. 95489

Wati, L.N.; Primiana, H.I.; Pirzada, K.; Sudarsono, R. 2019. Political connection, blockholder ownership and performance, Entrepreneurship and Sustainability Issues 7(1): 52-68. http://doi.org/10.9770/jesi.2019.7.1(5)

Watson, J \& McNaughton, M. (2007). Gender Differences in Risk Aversion and Expected Retirement Benefits. Financial Analysts Journal, 63(4): 52-62. http://dx.doi.org/10.2469/faj.v63.n4.4749

Watson, J \& Robinson, S. (2003). Adjusting For Risk In Comparing The Performances Of Male-and Female-Controlled SMEs. Journal of Business Venturing, 18(6): 773-788. http://dx.doi.org/10.1016/S0883-9026(02)00128-3

Wendy \& Asri, M. (2012). Psychological Biases in Investment Decisions: An Experimental Study of Myopic Behavior in Developing Capital Markets. Journal of Indonesian Economy and Business, 27(2): 143-158.

Yao, R., Gutter, M. S., \& Hanna, S, D. (2005). The Financial Risk Tolerance of Blacks, Hispanics and White. Financial Conseuling and Planning, 16(1): 51-62.

\section{Acknowledgements}

We would like to thanks to The Ministry of Research, Technology, \& Higher Education of The Republic of Indonesia for the Research Grant 2018 Period.

\section{Firda NOSITA}

ORCID.ID: https://orcid.org/0000-0003-3173-1300

\section{Kashan PIRZADA}

ORCID ID: https://orcid.org/0000-0003-1186-0631

\section{Tina LESTARI}

ORCID ID: https://orcid.org/0000-0002-8551-0602

\section{Rosadiro CAHYONO}

ORCID ID: https://orcid.org/0000-0002-2032-8121

This work is licensed under the Creative Commons Attribution International License (CC BY) http://creativecommons.org/licenses/by/4.0/ 